\title{
PROJETOS DE MODERNIZAÇÃO DO BRASIL (1870-1930) EM TRISTE FIM DE POLICARPO QUARESMA
}

\author{
the brazilian modernization projects (1870-1930) in Triste Fim de Policapor Quaresma
}

\author{
Artur Monteiro Leitão Júnior* \\ Rita de Cássia Martins de Souza Anselmo**
}

\begin{abstract}
Resumo
Este artigo se fundamenta sob a perspectiva de resgate dos discursos e das visões de mundo a partir da Literatura, buscando interpretar nos escritos do autor carioca Lima Barreto, mais especificamente na obra Triste Fim de Policarpo Quaresma, quais as interpretações que esse escritor desenvolveu acerca do espaço urbano do Rio de Janeiro e da sociedade fluminense - metonímia da sociedade brasileira -, submetida ao incipiente processo de modernização nacional (1870-1930). Para além das contribuições estilísticas importantes para a literatura do período, o enredo oferece uma fonte rica de análise para a identificação das visões de mundo expressas pelos intelectuais, o que, por extensão, significa a expressão do pensamento geográfico dos grupos sociais que cada um dos literatos buscava "dar voz" a partir de seus textos e discursos artísticos.
\end{abstract}

Palavras-chave: Pensamento Geográfico, Lima Barreto, Triste Fim de Policarpo Quaresma, Modernidade, Brasil.

\begin{abstract}
This article is methodologically based on the prospect of recovery of the discourses and world conceptions from the Literature, seeking to interpret in the Lima Barreto's writings, author native of Rio de Janeiro, specifically in his work Triste Fim de Policarpo Quaresma, which was the interpretations that this writer developed about the urban area of Rio de Janeiro and its society of Rio de Janeiro - metonymy of the Brazilian society -, submitted to the incipient process of national modernization (1870-1930). Apart from important stylistic contributions to the Literature of the period, the plot provides a rich source of analysis for the identification of world conceptions expressed by the intellectuals, which, by extension, means the expression of the geographical thought sustained by the social groups that each writer sought "giving voice"
\end{abstract} on their texts and artistic discourses.

Key words: Geographic Thought, Lima Barreto, Triste Fim de Policarpo Quaresma, Modernity, Brazil.

\section{Resumen}

Este artículo se basa en la perspectiva de rescatar los discursos y visiones del mundo de la Literatura, tratando de interpretar los escritos de Lima Barreto, autor nativo de Río de Janeiro, más específicamente en el trabajo Triste Fim de Policarpo Quaresma, que interpretaciones que este escritor desarrolló sobre el espacio urbano de Río de Janeiro y su sociedad sociedad de Rio de Janeiro - metonimia de la sociedad brasileña -, presentada a la incipiente proceso de modernización nacional (1870-1930). Además de las importantes contribuciones estilísticas a la literatura de la época, la trama ofrece una rica fuente de análisis a identificación de las visiones del mundo expresadas por el intelectuales, que, por extensión, significa la expresión del pensamiento geográfico de los grupos sociales que cada uno de los literatos buscaba "dar la palabra" a través de sus textos y sus discursos del arte.

Palabras-claves:Pensamiento Geográfico, Lima Barreto, Triste Fim de Policarpo Quaresma, Modernidad, Brasil.

(*) Mestrando em Geografia pela Universidade Federal de Uberlândia - Av. João Naves de Ávila, 2121, Santa Mônica, CEP: 38408-100, Uberlândia (MG), Brasil. Tel.: (+ 55 34) 32394169 - artur_ml_junior@yahoo.com.br

(**) Prof ${ }^{a}$. Dr ${ }^{\mathrm{a}}$ da Universidade Federal de Uberlândia - Av. João Naves de Ávila, 2121, Santa Mônica, CEP: 38408-100, Uberlândia (MG), Brasil. Tel.: (+ 55 34) 32394169 - ritacmsou@ig.ufu.br 


\section{INTRODUÇÃO}

O período entre o final do século XIX e o início do século XX é marcado profundamente pela necessidade de o Brasil ser reconhecido internacionalmente como uma grande nação, desvinculando-o dos estigmas de atraso, indolência e ociosidade de seus habitantes. Para tanto, instaurou-se, enquanto palavra de ordem dos discursos, o imperativo da modernidade, fundamentada em aspectos materiais - a partir de uma remodelação da estrutura e organização espacial e de um desenvolvimento técnico - e ideais - calcados nos princípios civilizatórios, referenciados na Europa Ocidental.

Sob o signo da modernização, os literatos da época, parcela significativa da elite intelectual brasileira, versavam acerca de como entendiam as condições políticas, culturais, sociais, econômicas e espaciais do Brasil daquele momento histórico. Isso representa para a história do pensamento geográfico uma fonte rica de análise para a identificação das visões de mundo expressas pelos escritores, o que, por extensão, significa a expressão das ideologias científicas e geográficas dos grupos sociais que cada um desses indivíduos expressivos, conforme conceituação de Lucien Goldmann (1979), "dava voz" a partir de seus textos e discursos artísticos .

Assim, este artigo se fundamenta sob essa perspectiva de resgate do pensamento geográfico a partir dos discursos veiculados pela Literatura. Busca interpretar a partir dos escritos do autor carioca Afonso Henriques de Lima Barreto, mais especificamente da obra Triste Fim de Policarpo Quaresma, quais as interpretações que esse escritor desenvolveu acerca do espaço urbano do Rio de Janeiro e da sociedade fluminense, submetida a intensos processos de transformação a partir das mudanças experimentadas pela sociedade brasileira naquele momento de modernização nacional (1870-1930).

Para além das contribuições estilísticas importantes para a literatura nacional do período, o enredo favorece a apreensão das concepções ideológicas de Lima Barreto/Policarpo Quaresma acerca da modernização. O protagonista vive três estágios diferentes na obra: um modesto funcionário público; um proprietário rural; e um soldado governista voluntário contra a Segunda Revolta da Armada (1893). Os três estágios correspondem a três níveis diferentes e complementares do universo fluminense, encarados aqui como uma metonímia da sociedade brasileira como um todo: a vida simples do subúrbio do Rio de Janeiro; o cotidiano familiar e político do interior (zona rural); e, a atmosfera política da Primeira República. Utilizando-se do quixotesco Quaresma, Lima Barreto - um dos mais veementes críticos de sua época - traça um perfil da sociedade e da organização espacial, política e cultural do Brasil no final do século XIX, expondo várias instâncias das reformas modernizadoras pensadas pelos intelectuais: a reforma pela cultura, a reforma pela agricultura e a reforma pela força militar. Para cada uma dessas reformas, Policarpo Quaresma encontra empecilhos que transformam o otimismo inicial a respeito da grandiosidade da pátria em um pessimismo devastador, cético quanto à viabilidade da efetivação do sonhado progresso pensado para o Brasil.

O artigo procede a uma discussão da Literatura como instrumento de compreensão da realidade, constituindo-se em uma rica fonte para a apreensão dos debates presentes em um dado recorte têmporo-espacial. Em seguida, parte-se para a apresentação do Pré-Modernismo enquanto estrutura significativa fundamental presente em Triste Fim de Policarpo Quaresma, destacando as suas características e contradições perante o movimento mais amplo da sociedade brasileira. Finalmente, apresenta-se o exame do pensamento barretiano e os discursos geográficos expressos na referida obra.

\section{A LITERATURA COMO INSTRUMENTO DE COMPREENSÃO DA REALIDADE}

O século XIX foi amplamente marcado pela "invenção" histórica do Estado-nação, em nível mundial, pautado na independência ou na soberania política, na unidade territorial ou legal e na construção de uma ideia de identidade nacional, ideologicamente operada por mitos de origem que promovessem a unificação de sociedades bastante fragmentadas social, política, cultural e econo- 
micamente. Nesse contexto, a ciência ganhou um novo estatuto, sendo operada, muitas vezes, em favor dessa nova causa em questão: a fundação das identidades nacionais debaixo das unidades territoriais.

Assim, a construção política e territorial dos Estados-nações articulou-se também à necessidade de incorporação das manifestações culturais, ensejando narrativas míticas que se configurassem como soluções para contradições e conflitos próprios à heterogeneidade social, de modo que esses mitos pudessem fundar uma concepção universalista, indivisível e inquestionável do conteúdo de uma nação, revestida de heróis e contos lendários . Essas distinções nacionais, aliadas aos projetos amplos de formações territoriais, definiram, em grande medida, os rumos da história do período para os "novos" Estados Nacionais.

No caso brasileiro, a redefinição da identidade nacional ocorreu paralelamente à instalação de um projeto de modernização entre as últimas décadas do século XIX e as três primeiras décadas do século XX. Para Machado (2006), os sessenta anos entre a promulgação da "Lei do Ventre Livre" (1871) e a dita Revolução de 1930 marcam, segundo a tradição historiográfica, a ascensão do projeto de modernização das elites nacionais, caracterizado pela transição do trabalho escravo para o trabalho livre, a acentuação das diferenças sociais e econômicas entre as regiões brasileiras, a sucessão da Monarquia pela República e o deslocamento do eixo principal do comércio brasileiro da Europa para os Estados Unidos.

Ainda segundo Machado (2006), essa redefinição foi pautada em um grupo ínfimo da população, o qual desenvolveu duas dimensões: um "olhar para dentro", criticando a sociedade estruturada em relações escravocratas, o que desafiava a fundação de uma racionalidade que fundamentasse a valorização do nacional; e um "olhar para fora", implicando na adoção de uma "razão classificatória" que estabelecesse a posição do Brasil ante as nações "progressistas". Foram essas dimensões que permitiram a incorporação de ideologias científicas - tais como o darwinismo social, o positivismo e o neolamarckismo - ao cenário intelectual brasileiro da época, estabelecendo o divisor de águas entre o Brasil colonial e o Brasil "moderno". Ao pensamento geográfico coube, grosso modo, "o estabelecimento do potencial e dos limites da natureza física, social e política do país diante das idéias programáticas do "progresso"”. (MACHADO, 2006, p.310).

Grosso modo, a segunda metade do século XIX foi marcada por grandes e profundas mudanças: em termos econômicos, observou-se a definitiva ascensão do café, a criação das instituições financeiras e as primeiras tentativas industriais. No plano social, destacaram-se os conflitos em torno da extinção do tráfico negreiro, da abolição da escravatura e a chegada dos imigrantes europeus, com suas respectivas culturas, de certo modo mais familiarizadas ao emprego livre nos campos e nas cidades. Foi também o tempo em que os caminhos pisados pelos burros de carga foram sendo substituídos pelas estradas de ferro, instaurando uma aura de progresso e modernidade, intensificada pelo início da urbanização acelerada.

O final do século XIX e o início do século XX foram marcados, portanto, por um turbilhão de mudanças que infestou a atmosfera intelectual e artística brasileira. Nos dizeres de Antônio Cândido (1987), a literatura, num país de analfabetos como era o caso do Brasil, exerceu uma função "devoradora", atuando como instrumento de imposição cultural e meio de integração das manifestações artísticas locais às tradições ocidentais. Nesse contexto, os discursos veiculados pelos textos literários assumiram posições ideológicas, em termos científicos e geográficos, acerca do modo de condução da formação territorial e da construção da identidade nacional brasileiras.

Nesse ponto, vale destacar que os discursos são aqui compreendidos enquanto instâncias que "colocam em funcionamento" a própria linguagem, relacionando sujeitos e sentidos afetados pela língua e pela história: em resumo, os discursos implicam na consideração das condições histórico-sociais e filiações ideológicas dos sujeitos discursivos (ou, no caso dos literatos, sujeitos-escritores), manifestantes de distintas tomadas de posição e concepções ou visões de mundo, que são estruturais a todos os discursos. No caso da Literatura, a arte literária se configura como um interessante aporte 
discursivo por permitir o "desafinamento" do "coro dos contentes", revestindo-se de uma candente aura de campo estratégico interessante para o "descortinamento" das forças e tensões pertinentes às estruturas sociais.

Entretanto, ao mesmo tempo em que a produção discursiva literária deve se reportar à sua origem genética centrada no seio histórico-social, também deve - por se tratar de uma instância artística - ser vislumbrada em sua autonomia estética, mantendo intactas as suas riquezas criativas e comunicativas: afinal, todo escritor possui uma liberdade criativa inerente, uma licença poética, levando em consideração que seus temas, motivos, valores, normas ou descontentamentos são guarnecidos, expressa ou ocultamente, pelas condições espaço-temporais (contexto histórico, social e geográfico) em que o literato (intelectual) se inscreve.

Assim sendo, esses textos não se mantêm neutros perante o momento político, uma vez que expressam, implícita ou explicitamente, determinadas orientações que buscam legitimidade e materialização no Real. Isso porque o próprio autor ocupa uma determinada posição no contexto literário à sua época, bem como uma determinada posição social:

[...] o escritor, numa determinada sociedade, é não apenas o indivíduo capaz de exprimir a sua originalidade, (que o delimita e especifica entre todos), mas alguém desempenhando um papel social, ocupando uma posição relativa ao seu grupo profissional e correspondendo a certas expectativas dos leitores ou auditores (CANDIDO, 1976, p.74).

Neste artigo, interessa-nos, além do contexto literário e do grupo de profissionais a que se liga o escritor Afonso Henriques de Lima Barreto, a posição social ocupada por este escritor, permitindo um maior entendimento da profundidade e da eficácia política de seu discurso.

Trata-se de um resgate do pensamento presente no autor, mas que, no entanto, não se limita ao literato Lima Barreto, expressando o embate de forças maiores presente na sociedade de seu tempo. Extrair desse discurso os embates é o que mais nos atrai no sentido de perscrutar quais proposições encontraram legitimidade ou eficácia política e quais se "perderam" na História. No caso desse autor em particular, levando em conta sua postura extremamente crítica e avessa aos fundamentos da sociedade capitalista e de seu desenvolvimento, talvez cheguemos mais próximo das "contracorrentes" ao pensamento dominante da época.

Não basta, como se pode prever, analisar as estruturas econômicas meramente, como se a base material pudesse, exclusivamente, dar conta da dinâmica, mas cabe resgatar, imprescindivelmente, as interrelações entre essa base e as estruturas ideais, na busca permanente e interminável da totalidade.

Cabe um trecho de Lucien Goldmann para nos auxiliar:

Acabamos de dizer que a compreensão é a evidenciação de uma estrutura significativa imanente ao objeto estudado [...] A explicação é simplesmente a inserção dessa estrutura, enquanto elemento constitutivo e funcional, em uma estrutura imediatamente globalizante, que o pesquisador não explora, no entanto, de maneira detalhada, mas somente na medida em que isso é necessário para tornar inteligível a gênese da obra que ele está estudando. Entretanto, basta tomar como objeto de estudo a estrutura globalizante para que o que era explicação se torne compreensão e para que a pesquisa tenha de se reportar a uma nova estrutura mais ampla. (GOLDMANN, 1993, p.66, grifos do autor).

O estruturalismo genético de Goldmann serve-nos aqui como guia na busca da "máxima consciência possível" em Lima Barreto.

Destarte, trabalha-se aqui com a correlação entre a Arte e a Ciência - ou, mais precisamente, entre a Literatura e a Geografia -, buscando entrever na Literatura um privilegiado aporte discursivo que permite investigar, de maneira lato sensu, a sociedade (e o seu espaço correlato) a partir da qual são geradas as obras artístico-literárias, incluindo não somente a sua materialidade/concretude, sua configuração e organização, mas também as suas representações e os seus projetos territoriais. 
Representações e projetos inerentes, por exemplo, às propostas de formação territorial e de "aproveitamento" socioeconômico e político do território nacional.

Sob esse pressuposto de investigação dos discursos literários em suas estruturas históricas, sociais e ideológicas, as pesquisas desenvolvidas no entrecruzamento da Geografia com a Literatura buscam evitar uma mera "catalogação da Arte", em que as obras literárias sejam usadas como "adornos" de explicações geográficas dadas a priori, reduzindo ou limitando a sua capacidade legítima de ensejar reflexões e conhecimentos novos e autênticos. É a perspectiva discursiva, alicerçada em uma pretensão de verificação da eficácia política desses discursos, que permite, portanto, abrir novas possibilidades para os estudos relacionais entre Geografia e Literatura, diferentes, em grande medida, das produções usuais nesse campo investigativo-científico .

\section{O PRÉ-MODERNISMO BRASILEIRO}

O período de 1900 a 1922 é marcado por uma multiplicidade de manifestações literárias: convivem "desde os poetas parnasianos e simbolistas, que continuavam a produzir, até os escritores que começavam a desenvolver um novo regionalismo, além daqueles mais preocupados com uma literatura política e outros, ainda, com propostas realmente inovadoras" (DE NICOLA, 1998, p.248). Assim, o que se convencionou chamar de Pré-Modernismo - nomenclatura estabelecida por Tristão de Atayde - designa os textos literários que não seguiam, em algum ou vários aspectos, as diretrizes estilísticas e temáticas das escolas literárias pretéritas com as quais buscava romper (Romantismo, Parnasianismo, Simbolismo, Naturalismo e Realismo).

O Pré-Modernismo deve ser entendido, conforme Alfredo Bosi (1973), em dois sentidos, até mesmo contrastantes: no primeiro, o prefixo pré assume a postura de uma anterioridade temporal, sustentando os traços conservadores, esteticamente antimodernistas, e mantendo as tendências realistas, naturalistas e parnasianas. No segundo, o prefixo conota uma antecipação temática e formal dos valores renovadores modernistas, adotando posturas mais contundentes e críticas à realidade brasileira. De acordo com Penteado Martha (2000):

[...] graças a essa visão de Alfredo Bosi, é possível estabelecer uma significativa distinção entre os escritores que compõem o campo intelectual do início do século. Mesmo porque seria difícil, senão impossível, abrigar escritores como Amadeu Amaral, Martins Fontes (neoparnasianos) e prosadores acadêmicos como Rui Barbosa e Coelho Neto sob o mesmo manto de produtores como Euclides da Cunha, Monteiro Lobato, Graça Aranha e Lima Barreto, em cuja textura encontramos participação social, ironia e crítica (PENTEADO MARTHA, 2000, p.3).

Antônio Cândido (1976), em linhas gerais, entende o Pré-Modernismo como um período literário de permanência, conservando os padrões estéticos realistas-naturalistas pautados na busca pela perfeição formal. Entretanto, este período também reserva exceções significativas, como as obras de escritores como Alphonsus de Guimarães, Augusto dos Anjos e Lima Barreto, delatoras de preocupações políticas e sociais mais profundas.

Conforme Infante (2001), o Pré-Modernismo marcou uma época de um nacionalismo crítico e inovador, de modo que a literatura passou a ser concebida como um instrumento de ação social, permitindo conhecer a realidade e, assim, aumentar nossa capacidade de convivência e organização. Todavia, essa concepção de literatura afastava-se do ideal literário cultivado pelos governantes do país, os quais preferiam um nacionalismo mais ufanista e uma literatura "mais bem comportada". A esse respeito, Infante (2001, p.384) comenta:

Uma literatura que preferia tematizar as enormes diferenças sociais do país em vez de louvar o "progresso" nacional era, sem dúvida, um desagradável empecilho à propaganda oficial, que procurava passar a idéia de que a República, recém-consolidada pela chamada "política café-com-leite" (a aliança 
entre os produtores de café paulistas e os criadores de gado leiteiro de Minas Gerais), era efetivamente um caminho modernizador e democratizante para o país. (INFANTE, 2001, p.384).

A descoberta do Brasil "não-oficial" foi, portanto, o grande mérito da prosa pré-modernista, uma vez que permitiu a expressão do nacionalismo crítico e progressista em detrimento do nacionalismo conservador oficial e, por consequência, a manifestação dos tipos humanos marginalizados. Ademais, o Pré-Modernismo também introduziu uma renovação da linguagem literária: ao lado da poetização da linguagem científica, incorporou-se o uso de regionalismos, de formas da linguagem popular ou de um estilo mais simples e despojado, próximo à linguagem jornalística (INFANTE, 2001).

É no interior dessa acepção do Pré-Modernismo crítico, calcado em um nacionalismo progressista, que encontramos a obra de Lima Barreto.

\section{LIMA BARRETO: um "estrangeiro" no Rio de Janeiro}

Afonso Henriques de Lima Barreto nasceu no Rio de Janeiro, em 1881. Mulato, de origem humilde, dedicou sua obra a desmascarar a falsidade dos poderosos. Realizou os seus estudos preparatórios no Colégio Pedro II, ingressando, posteriormente, na Escola Politécnica do Rio de Janeiro, a qual abandonaria antes da formatura a fim de assegurar o seu próprio sustento a partir do funcionalismo público. Dedicou-se ao jornalismo e à literatura de crítica social, atividades que foram alvos de muitas polêmicas e que lhe renderam inúmeras críticas. Sua vida foi marcada por profundos desenganos e humilhações, em parte causados pela loucura de seu pai - gerando a internação do próprio Lima Barreto em casa de "desajustados mentais". A boemia e o alcoolismo, porém, parecem não ter interferido em seu trabalho intelectual, mas o levaram à morte prematura, em 1922, aos 41 anos.

A sua produção literária foi diversificada, incluindo romances, contos, crônicas, sátiras políticas, críticas literárias e um livro de memórias. Entre as suas obras destacam-se: Recordações do Escrivão Isaías Caminha (1909); Triste Fim de Policarpo Quaresma (1915); Numa e Ninfa (1915); Vida e Morte de M.J. Gonzaga de Sá (1919); o livro de contos Histórias e Sonhos (1920); a sátira política Os Bruzundangas (1923); Clara dos Anjos (1948); e o romance autobiográfico sobre sua experiência no hospício $O$ Cemitério dos Vivos (1953). Note-se que parte da sua obra foi publicada após a sua morte, resultado de esforços de compilação dos textos encontrados em jornais e revistas com os quais colaborou.

A obra é marcada por um estilo em que a paixão se sobrepõe à inteligência e à técnica da perfeição estética. É reconhecido que desenvolveu uma obsessão pela literatura como forma de extravasar sua irreprimível necessidade de explorar temas ligados à sua própria vida. Aborda, constantemente, temas ligados ao preconceito da sociedade da época contra os mestiços e pobres, apresentando sempre uma indignação contra a insensibilidade dos ricos, a superficialidade dos burocratas, a corrupção dos políticos e a esterilidade dos falsos artistas.

Para Lima Barreto, a literatura possuía um caráter militante, uma "missão social, de contribuir para a felicidade de um povo, de uma nação, da humanidade" (BARRETO, 1907 apud ROSSO, 2006). Rosso (2006) expressa as concepções barretianas sobre a arte literária:

Parece-me que o nosso dever de escritores sinceros e honestos é deixar de lado todas as velhas regras, toda a disciplina exterior dos gêneros, e aproveitar de cada um deles o que puder e provocar, conforme a inspiração própria, para tentar reformar certas usanças, sugerir dúvidas, levantar julgamentos adormecidos, difundir as nossas grandes e altas emoções em face do mundo e do sofrimento dos homens, para soldar, ligar a humanidade em uma maior, em que caibam todas, pela revelação das almas individuais e do que elas têm em comum e dependente entre si. [...] Não desejamos mais uma literatura contemplativa, o que raramente ela foi; não é mais uma literatura plástica que queremos, a encontrar 
beleza em deuses para sempre mortos, manequins atualmente, pois a alma que os animava já se evolou com a morte dos que os adoravam. Não é isso que os nossos dias pedem; mas uma literatura militante para maior glória da nossa espécie na terra e mesmo no Céu (BARRETO, 1907 apud ROSSO, 2006).

O tom literário militante de Lima Barreto, oposto à escrita floreada e vazia, aristocrática e fútil da maioria dos seus contemporâneos, apresenta um caráter de denúncia, cujas temáticas principais, em essência, referiam-se à discriminação social e racial, ao preconceito de cor, ao vazio moral, intelectual e ético dos políticos, à ganância e ambição, ao arrivismo, ao bovarismo, à miséria e opressão social (ROSSO, 2006). A obra ficcional barretiana apresenta, segundo Rosso (2006), algumas linhas recorrentes: obsessão pela origem, marcas da religiosidade, evocação do mistério e da surpresa, emocionadas descrições dos subúrbios cariocas, as periferias urbanas, as divisões de classes, a exclusão social, os pobres e os enjeitados e os traços da raça. Em todas essas linhas, o escritor apresenta grande perspicácia na descrição e análise da realidade brasileira, gerando um tema nuclear - o poder e seus efeitos discricionários em torno do qual, seus registros apresentam-se emocionados e opinativos, quase sempre sarcásticos, satíricos e irônicos (ROSSO, 2006).

A literatura contemporânea encontrou em Lima Barreto uma contribuição importante: o abandono do modo artificial e erudito de escrever, adotado em ampla medida pelos literatos da época. Ao contrário, o autor buscou aproximar-se da linguagem cotidiana, colaborando para uma descontração e objetividade das frases, o que agradou parte dos escritores modernistas da Semana da Arte Moderna de 1922. A esse respeito, Milliet (1948) escreveu:

Lembro-me da grande admiração que tinha por Lima Barreto o grupo paulista de 22. Alguns entre nós, como Alcântara Machado, andavam obcecados. O que mais nos espantava então era o estilo direto, a precisão descritiva da frase, a atitude antiliterária, a limpeza de sua prosa, objetivos que os modernistas também visavam. Mas admirávamos por outro lado sua irreverência fria, a quase crueldade científica com que analisava uma personagem, a ironia mordaz, a agudeza, que revelava na marcação dos caracteres (MILLIET, 1948).

De acordo com Bosi (1992), Lima Barreto deprimia-se com o universo de citações de onde os letrados exibiam aos seus pares o domínio sobre o outro, com uma mistura sertanejo-parnasiana de curiosidade, folclorismo e poder cultural. Esse modelo hermético de escrita era derivado de um fetiche com o estrangeirismo, com o qual Lima Barreto, a partir de suas análises e críticas da sociedade carioca, se impacientava: "Se toda exploração do pobre, do mulato, do caboclo, do nosso povo, o constrangia, de igual modo o irritava a sua contraparte, fatal nas burguesias periféricas, que é o mimetismo de modas e signos comprados aos centros de prestígio" (BOSI, 1992, p.269).

$\mathrm{O}$ autor caracterizou-se por produzir obras que se aproximaram do estilo naturalista, sem, todavia, o rigor científico característico de tal escola literária (BARRETO, 1997). Ainda sim, ele conseguiu registrar com minúcia muitos aspectos da vida social e política do Rio de Janeiro no tempo da Primeira República, fornecendo um painel interessante da sociedade fluminense, a partir da expressão de alguns de seus personagens: o burocrata, o escriturário, o jornalista, o artista, o militar de baixa patente, o imigrante. Apesar de influenciado pela obra de Machado de Assis, de Dostoievski e dos positivistas franceses, como Taine e Brunetière, Lima Barreto se configura como um dos autores mais independentes de nossa ficção, acreditando na literatura como expressão direta dos sentimentos e ideias pessoais do escritor, dando, assim, um caráter autobiográfico a quase todos os seus romances.

As obras barretianas, em geral, tecem ácidas críticas ao espírito social do final do século XIX e início do século XX, calcado no ideal do 'progresso' veiculado pelos partidários da República. Segundo Melo (2003), a proclamação da República ensejou a substituição dos fazendeiros e antigos proprietários pelos especuladores do encilhamento, pelos militares e pelos propagandistas de uma nova fé, novos homens que, aos olhos dos monarquistas, eram a sombra da decadência, frutos da 
desordem dos novos tempos, não guardando maneiras e estilos, sendo rudes e grosseiros. Esses novos personagens cultivavam uma crença obsessiva nas ideias de progresso e civilização, fazendo emergir valores obscuros e uma ética duvidosa (MELO, 2003).

Nascido sob a égide do regime imperial, Lima Barreto não via com bons olhos os rumos das transformações sociais, políticas, econômicas, culturais e espaciais do final do século XIX, acreditando no efeito devastador da febre de enriquecimento a todo custo - arrivismo - substituindo os padrões morais e de honestidade dos homens da época imperial. É essa sociedade degringolada, bem como a cidade em que atua, o elemento de interpretação do autor carioca, marcando suas obras ficcionais com um tom pessimista acerca da instabilidade social e econômica marcante dos primeiros anos do regime republicano, permitindo-lhe considerar os espaços da cidade como locais de sofrimento e tortura.

Esse comportamento interessado exclusivamente em galgar posições a partir do enriquecimento a qualquer custo sempre preocupou e enojou Lima Barreto, sendo notado inclusive no meio intelectual: ainda estudante da Escola Politécnica do Rio de Janeiro, o escritor relata, em seu Diário Íntimo (1899), o estranhamento que tivera da multidão e dos estudantes, filhos de uma geração que tivera a ascensão social proveniente do encilhamento (MELO, 2003). Essa geração de arrivistas, nascida com a República e acomodada à nova situação, é alvo das críticas irreverentes de Lima Barreto, apesar de essa nova elite desvencilhar-se das acusações de corrupção, fraudes eleitorais, desrespeito aos trabalhadores e falcatruas com um novo discurso:

Enquanto a imprensa e a literatura da época denunciava (sic!) o "arrivismo agressivo" e a "corrupção destemperada" os políticos republicanos pintavam um quadro idílico a respeito do novo regime de governo que eles diziam estar fundado na "honestidade", na ordem, na "felicidade" e no "progresso" (MELO, 2003, p.546, grifos da autora).

Sentindo na pele o preconceito e a privação, simpático para com os humilhados, ofendidos e os suburbanos e crítico corrosivo contra a burguesia bem posta na vida, a hipocrisia e as falsas aparências, Lima Barreto sentia-se como o jovem Isaías, de sua obra Recordações do escrivão Isaías Caminha. Como comenta Bosi (1992), este personagem, ao entrar na cidade grande, metaforiza a condição intelectual do mestiço ou do negro que se percebe ao mesmo tempo livre e confinado sob a cor da pele, com "a sensação de estar em país estrangeiro". Eis a situação do escritor: um "estrangeiro" na sociedade carioca de sua época.

\section{TRISTE FIM DE POLICARPO QUARESMA: estilo literário e discurso geográfico}

Triste Fim de Policarpo Quaresma foi publicado em folhetim em 1911, ganhando uma versão em livro em 1915. Esse romance é um dos herdeiros do Naturalismo, preocupando-se em apresentar uma sátira do Brasil oficial, analisado sob a ótica de um patriota exaltado - o major Quaresma. A narração pauta-se na vida de um modesto funcionário público, em três estágios diferentes, correspondentes, mais ou menos, às três partes da obra: a sua vida como funcionário público; as suas aventuras enquanto proprietário rural; e, por fim, a sua vida como soldado voluntário da Segunda Revolta da Armada (1893). Paralelamente ao destino de Policarpo Quaresma, o romance também enfoca o universo fluminense em três níveis diferentes e complementares: a vida simples do subúrbio da capital; o cotidiano familiar e político da zona rural; e, a atmosfera política da Primeira República.

"Você, Quaresma, é um visionário...”! Essa frase expressiva dá a tônica principal do personagem Quaresma, um visionário, sonhador, patriota exaltado, dominado pela ideia de um Brasil acolhedor e amável. Ufanista, ele vê o país como um recanto de farturas, facilidades, compreensão e amor, visão que orienta o seu projeto de reforma nacional, dividido, assim como a obra e a vida do protagonista, em três etapas: uma reforma cultural; uma reforma agrícola; e, por fim, uma reforma política. O resultado dessa caminhada ufanista é a constatação de um país inóspito, precário, 
infecundo, cruel, autoritário e odioso. Destarte, o autor parte da concepção mítica do Brasil, e, a partir dela, desconstrói esse mito romântico conforme uma postura de comprovação da distância entre o sonho e a realidade, apresentando os idealismos românticos como uma utopia irrealizável.

Lima Barreto, por meio do sonho patriótico de Policarpo Quaresma, também pôde expor algumas temáticas fundamentais para a formação de seu ideário: a crítica à posição negativa do brasileiro médio em relação ao colonizador europeu; a exaltação a terra; a idealização da natureza virgem; a pesquisa folclórica; a denúncia contra o preconceito racial; a paródia da máquina burocrática estatal; e, o repúdio aos falsos artistas. Aproveitando-se da sua experiência enquanto funcionário público, Lima Barreto transportou para sua obra uma crítica pautada em sua vivência, caracterizando, de modo detalhado, os traços desse modelo de serviço; esse retrato do funcionalismo público da época - cujo representante mais destacado é o próprio presidente da República - alicerça-se em uma visão caricatural, representando uma alegoria contra a burocracia, formada por pessoas sem consistência moral ou profissional, como os generais sem batalha ou os almirantes sem navio (individualizados, respectivamente, nas figuras de Albernaz e Caldas).

Esse quadro caricatural estendido aos militares brasileiros é bastante explorado por Lima Barreto, entendendo-os, em grande parte, como interesseiros e mesquinhos, sem preocupações verdadeiras e profundas com o engrandecimento da pátria. Segundo Bittencourt (1956 apud MELO, 2003) formou-se, durante a Regência (1831-1840), uma polícia que atuaria na sua "zona de influência", composta de homens de autoridade moral - os militares da Guarda Nacional, ligados aos latifundiários -, debelando o espírito de dissolução da pátria; no Segundo Reinado (1840-1889), essa Guarda Nacional recebeu grande importância, sendo uniformizada e regulamentada, recebendo privilégios e elevando o rendimento provindo das patentes, transformando a categoria numa das principais receitas do orçamento nacional. Segundo Melo (2003), Lima Barreto vê com pesar e desilusão a continuidade das velharias - como era o caso dessa estrutura militar obsoleta - que deveriam ser superadas.

Esses personagens do quadro militar brasileiro são alvos das críticas de Lima Barreto, que repudia a mercantilização do prestígio e do poder a partir do pagamento de emolumentos, como ocorria com a compra dos títulos nobiliárquicos na nobreza europeia medieval; o próprio Quaresma é incorporado nesse vício nacional de tratamento dos considerados "homens superiores", sendo resguardado, porém, pelo autor como um caso mal-entendido:

Quaresma então explicou, por que o tratavam por major. Um amigo, influência do ministério do Interior, lhe tinha metido o nome numa lista de guardas-nacionais, com esse posto. Nunca tendo pago os emolumentos, viu-se, entretanto, sempre tratado major, e a coisa pegou. A princípio, protestou, mas como teimassem deixou (BARRETO, 1997, p.129).

Triste Fim de Policarpo Quaresma assume uma postura iconoclasta, desrespeitando e dessacralizando as tradições. Por isso, essa obra afasta-se das obras românticas e se aproxima do Realismo e do Naturalismo do final do século XIX. Apesar de não manter-se preso aos rigores naturalistas, Lima Barreto ainda trabalha com o conceito de literatura como instrumento de denúncia social, dando, às vezes, um enfoque panfletário às suas obras. Essa arte engajada na defesa dos princípios humanitários é expressa nos ataques ao positivismo republicano e na defesa da massa sofredora, localizados, especialmente, no último capítulo da segunda parte e em toda a terceira parte; outro exemplo do engajamento encontra-se na descrição afetuosa de Lima Barreto/Policarpo Quaresma das pessoas humildes, seja do subúrbio carioca ou das personagens secundárias da roça de Quaresma, localizada no território fluminense. O que fica claramente exposto, em ambos os casos, é o registro simples e objetivo da realidade, destacando os contrastes e desigualdades entre os dois "Brasis": o rico e o pobre. É essa postura que é valorizada amplamente nas obras pré-modernistas, das quais Triste Fim de Policarpo Quaresma é uma das suas maiores expressões. 
Lima Barreto contrapõe-se ao positivismo e, consequentemente, aos seus desígnios e ditames para o progresso e a modernização do país, considerando-o como uma "fé cega", exercida por fanáticos:

Os militares estavam contentes, especialmente os pequenos, os alferes, os tenentes e os capitães. Para a maioria a satisfação vinha da convicção de que iriam estender a sua autoridade sobre o pelotão e a companhia, a todo esse rebanho de civis; mas, em outros muitos havia sentimento mais puro, desinteresse e sinceridade. Eram os adeptos desse nefasto e hipócrita positivismo, um pedantismo tirânico, limitado e estreito, que justificava todas as violências, todos os assassínios, todas as ferocidades em nome da manutenção da ordem, condição necessária, lá diz ele, ao progresso e também ao advento do regime normal, a religião da humanidade, a adoração do grão-fetiche, com fanhosas músicas de cornetins e versos detestáveis, o paraíso enfim, com inscrições em escritura fonética e eleitos calçados com sapatos de sola de borracha!...

Os positivistas discutiam e citavam teoremas de mecânica para justificar as suas idéias de governo, em tudo semelhante aos canatos e emirados orientais (BARRETO, 1997, p.115).

Com uma grande sensibilidade analítica, o autor descreve os subúrbios cariocas, mostrando a (des)organização do espaço, fruto de uma urbanização galopante e de um crescimento demográfico desordenado. A todo o momento, o escritor compara o espaço urbano carioca aos espaços urbanos europeus, sob a perspectiva de criticar indiretamente a postura da capital nacional em se espelhar obsessivamente no exterior ou mesmo de censurar a visão positivista de consolidação do Brasil como um país "nos trilhos da modernidade e da civilização", ideais referenciados na Europa Ocidental, os quais, confrontados com a realidade, não se confirmavam.

Os subúrbios do Rio de Janeiro são a mais curiosa coisa em matéria de edificação de cidade. A topografia do local, caprichosamente montuosa, influi decerto para tal aspecto, mas influíram, porém, os azares das construções.

Nada mais irregular, mais caprichoso, mais sem plano qualquer, pode ser imaginado. As casas surgiram como se fossem semeadas ao vento e, conforme as casas, as ruas se fizeram. Há algumas delas que começam largas como boulevards e acabam estreitas que nem vielas; dão voltas, circuitos inúteis e parecem fugir ao alinhamento reto com um ódio tenaz e sagrado.

Às vezes sucedem na mesma direção com uma freqüência irritante, outras se afastam, e deixam de permeio um longo intervalo coeso e fechado de casas. Num trecho, há casas amontoadas umas sobre as outras numa angústia de espaço desoladora, logo adiante um vasto campo abre ao nosso olhar uma ampla perspectiva. [...]

Não há nos nossos subúrbios coisa alguma que nos lembre os famosos das grandes cidades européias, com as suas vilas de ar repousado e satisfeito, as suas estradas e ruas macadamizadas e cuidadas, nem mesmo se encontram aqueles jardins, cuidadinhos, aparadinhos, penteados, porque os nossos, se os há, são em geral pobres, feios e desleixados (BARRETO, 1997, p.78).

Antes que proceder a uma crítica aos subúrbios, Lima Barreto descreve esse espaço urbano como uma forma de dar vazão às suas observações perspicazes, desenterrando os "homens do subterrâneo", trazendo-os à tona, mostrando as suas "caras" e as suas condições de vida. Simpático a essa classe dos humilhados e dos pobres, o escritor pretende retratar o destino do genuíno brasileiro, ignorado pelas classes dirigentes.

Esse entendimento da formação nacional brasileira, do ponto de vista do "habitat" urbano, representa um ponto de maturidade desse escritor, cético quanto aos modelos simplesmente racionais de organização do espaço, compreendendo que a expressão espacial da sociedade também era fruto de decisões e vontades políticas. Essas descrições geográficas também se desenvolvem para os espaços urbanos das vilas, dos interiores rurais e para as "roças" da zona rural: "O que mais a [Olga] impressionou no passeio foi a miséria geral, a falta de cultivo, a pobreza das casas, o ar 
triste, abatido da gente pobre" (BARRETO, 1997, p.97). Nesses rincões, onde se manifestavam os caboclos e típicos brasileiros, Lima Barreto mostra sua descrença para explicar a situação de miséria e penúria da população a partir de explicações referenciadas no evolucionismo spenceriano ou no darwinismo social: "Não podia ser preguiça só ou indolência. Para o seu gasto, para uso próprio, o homem tem sempre energia para trabalhar" (BARRETO, 1997, p.97).

A esse respeito, creditava a pobreza da grande massa populacional brasileira (ligada ao rural) ao objetivo da administração republicana em beneficiar e enriquecer exclusivamente a antiga nobreza agrícola e conservadora, reservando-lhe, por exemplo, pagamentos de tributos, pagamentos dos custos da imigração e auxílios à lavoura (BOSI, 1992).

Portanto, a verve artística barretiana esteve focada, sobremaneira, na organização e na vida dos subúrbios (e dos suburbanos) ou nos pobres "esquecidos" dos ambientes cujos modus vivendi era rural, mesmo que manifestos sob a forma de pequenas cidades ou vilas. A precariedade que Lima Barreto queria expor transcendeu a sua obra-prima, sendo recorrente ao longo de toda a sua produção; assim, as condições nefastas que compunham o quadro das imagens irradiadas pelos bairros pobres dos subúrbios também podem ser notadas, por exemplo, no romance Clara dos Anjos:

Havia casas, casinhas, casebres, barracões, choças por toda a parte onde se possa fincar quatro estacas de pau e uni-las por paredes duvidosas. Todo o material para essas construções serve: são latas de fósforos distendidas, telhas velhas, folhas de zinco, e, para as nervuras das paredes de taipa, o bambu, que não é barato. Há verdadeiros aldeamentos dessas barracas, nas covas dos morros, que as árvores e os bambus escondem aos olhos dos transeuntes. Nelas há quase sempre uma bica para todos os habitantes e nenhuma espécie de esgoto. Toda essa população pobríssima vive sob ameaça constante da varíola e, quando ela dá pra aquelas bandas, é um verdadeiro flagelo. (BARRETO, 1956, v.V, p.115 apud SEVCENKO, 2003, p.76).

Foi esse mesmo tom ácido e crítico que o literato usou para desdenhar os símbolos da reforma urbana do Rio de Janeiro no início do século XX, contrapondo-se à civilidade e à modernidade importadas e "vencedoras" em nossa Belle Époque Tropical, percebendo as contradições e o mal- estar que as transformações do espaço urbano do Rio de Janeiro e a chegada dos novos padrões republicanos acarretavam . Com essa argúcia, Lima Barreto valeu-se como defensor da preservação da história e da memória do Rio, ao mesmo tempo em que combateu com devoção a pesada herança colonial de uma sociedade escravocrata, refletida na perpetuação das desigualdades sociais e da privação dos direitos dos negros africanos e seus descendentes (FREITAS, 2005). O que realmente incomodava o literato era a aceleração das mudanças, revelando um turbilhão em meio ao qual os ideais perdiam os seus referenciais e seus sensos morais apurados; no extravasamento dessa sua angústia, ele escreveu: "De uma hora para outra, a antiga cidade [do Rio de Janeiro] desapareceu e outra surgiu como se fosse obtida por uma mutação de teatro. Havia mesmo na cousa muito de cenografia". (BARRETO, 1956, v.VII, p.106 apud SEVCENKO, 2003, p36).

Sob os anseios de mimese ou sintonia da Capital - a qual era, na verdade, uma metonímia para as propostas e reformas que se pretendia para o Brasil como um todo - em relação a outros centros cosmopolitas, como Buenos Aires, Lima Barreto era irônico e sarcástico ao deparar-se com a elitista sanha da aparência moderna:

A obsessão de Buenos Aires sempre nos perturbou o julgamento das coisas.

A grande cidade do Prata tem um milhão de habitantes; a capital argentina tem longas ruas retas; a capital argentina não tem pretos; portanto, meus senhores, o Rio de Janeiro, cortado de montanhas, deve ter largas ruas retas; o Rio de Janeiro, num país de três ou quatro grandes cidades, precisa ter um milhão; o Rio de Janeiro, capital de um país que recebeu durante quase três séculos milhões de pretos, não deve ter pretos. [...]

O Rio civiliza-se! (BARRETO, 1915). 
Este literato, que também era cronista, debochava da aparente civilidade da Capital, palco sim de transformações grandiloquentes - sintetizadas no slogan "O Rio civiliza-se", ironizado pelo literato na última frase da crônica -, mas sem um significado profundo de instauração da sonhada modernidade, uma vez que a população era deixada à margem do processo, não sendo reservados a ela os ganhos efetivos da cidadania e das melhores socioeconômicas: por isso, Lima Barreto considerava tais ações como meras cenografias, cujas feições reais estavam muito aquém das imagens e construções imaginárias que lhe eram conferidas.

Assim, crítico ferrenho aos projetos elitistas e autoritários de construção do espaço, a postura oposicionista de Lima Barreto ia além: se no plano social, por um lado, ele buscava denunciar uma realidade de desigualdades, por outro, no plano artístico e estético, ele também forjava as suas retórias artístico-literárias como plataformas críticas ao seu tempo.

Por isso, seguindo o ideal estético de Lima Barreto, Triste Fim de Policarpo Quaresma pauta-se na objetividade, em frases comuns e em uma narrativa simples, espontânea e natural. Há uma passagem na própria obra que versa sobre a leitura 'hermética' criticada pelo autor:

De fato, ele [Armando Borges] estava escrevendo ou mais particularmente: traduzia para o clássico um grande artigo sobre "Ferimentos por armas de fogo". O seu último truque intelectual era este do clássico. Buscava nisto uma distinção, uma superação intelectual desses meninos por aí que escrevem contos e romances nos jornais. Ele, um sábio, e sobretudo um doutor: não podia escrever da mesma forma que eles. A sua sabedoria superior e o seu título acadêmico não podiam usar da mesma língua, dos mesmos modismos, da mesma sintaxe que esses poetastros e literatos. Veio-lhe então a idéia do clássico. O processo era simples: escrevia do modo comum, com as palavras e o jeito de hoje, em seguida invertia as orações, picava o período com vírgulas e substituía incomodar por molestar, ao redor por derredor, isto por esto, quão grande ou tão grande por quamanho, sarapintava tudo de ao invés, empós, e assim obtinha o seu estilo clássico que começava a causar admiração aos seus pares e ao público em geral (BARRETO, 1997, p.131, grifos do autor).

Essa passagem se refere a Armando Borges, um médico sem talento ou convicção científica que, para parecer mais importante e obter prestígio, compilava as noções de Medicina em artigos com expressões eruditas, copiadas dos clássicos, as quais ele não entendia ou assimilava seus significados. Assim, ao criticá-lo, Lima Barreto adota uma postura totalmente contrária ao estilo artificial e caricatural da Belle Époque brasileira - personificada, por exemplo, em Rui Barbosa, Coelho Neto, Afrânio Peixoto e Alberto de Oliveira -, modelo que decididamente evitava. De fato, o romance - assim como toda a obra de Lima Barreto - adotou um viés da leitura fácil e dinâmica. Esse caráter transmitiu ao Modernismo como captar de maneira viva a agitação das ruas do Rio de Janeiro, expressa nas mais diversas camadas da população: o burocrata, o escriturário, os moleques, os oficiais, os soldados, o imigrante, a dona de casa, a moça preocupada com a moda, o seresteiro, a ex-escrava, os trabalhadores etc..

O diletantismo é alvo constante de crítica nas obras barretianas. Conforme Melo (2003), a República deu continuidade à "superstição do doutor", pela qual Lima Barreto nutria um verdadeiro horror pelo fato dos bacharéis serem arrogantes: os doutores se consideravam acima de todos os reles mortais, obtendo privilégios especiais, constantes nas leis ou consignados nos costumes. O fetiche do diploma permitira que os cargos técnicos e de direção passassem para os "doutores", criando novos cargos para eles e passando por cima daqueles de verdadeira competência, os quais exerciam suas profissões por experiência e talento (MELO, 2003). Entretanto, ante a sagacidade crítica de Lima Barreto, essa postura de semideuses era totalmente injustificada diante do artificialismo e do superficialismo dos conhecimentos e saberes desses "doutores".

Para além da contribuição estilística, a obra Triste Fim de Policarpo Quaresma guarda, na esfera discursiva, concepções ideológicas interessantes acerca dos projetos de Policarpo Quaresma para salvar o país. Na primeira parte, a vida do funcionário público é relatada, com seus hábitos 
arraigados e conservadores no subúrbio do Rio; sua obsessão, naquele momento, era salvar o país por uma reforma nos costumes (uma reforma pela cultura). Imbuído nesse intuito, o protagonista pôs-se a estudar folclore e o tupi-guarani, pois acreditava que o homem brasileiro deveria se expressar fundamentalmente a partir de suas raízes - ou seja, como os primitivos tupinambás - e não como os europeus. Nesse sentido, fica clara a intenção de resgate de uma cultura vernácula, expressada magistralmente pela intenção em substituir a língua portuguesa (claramente uma das manifestações culturais mais fortes) pelo tupi, o qual, enquanto língua original brasileira, deveria ser amplamente estudado e aprendido a fim de transformar-se na língua oficial.

Essa postura ufanista acaba rendendo ao major Quaresma um estatuto de loucura, sendo metido, então, em um sanatório. Ao sair do hospício, Quaresma havia desistido do seu intuito de reformar o país pelos costumes, acreditando na solução a partir de uma reforma da agricultura; para tanto, ele adquire o Sítio Sossego para servir, aos compatriotas, de exemplo da fecundidade da terra brasileira - meio de conseguir o avanço brasileiro, a tão sonhada modernidade. Todavia, em pouco tempo ele é vencido pela má qualidade da terra, pelas saúvas e pela mesquinharia da política local. Arrasado, ele decide voltar para o Rio de Janeiro para salvar a Pátria do perigo representado pela Revolta da Armada, que eclodira na capital brasileira. Assim, envia um telegrama ao próprio presidente, com os seguintes dizeres: "Marechal Floriano. Rio. Peço energia. Sigo já. Quaresma".

A partir desse ponto, desenrola-se a terceira parte da obra, na qual Quaresma tenta transformar o país a partir de uma reforma política. Alistando-se ao Exército a favor de Floriano Peixoto, Policarpo Quaresma foi designado para comandar um batalhão de 40 soldados. Obtém uma entrevista com o presidente da República, mas sai absolutamente decepcionado com a figura displicente e preguiçosa do líder, desacreditando nas reformas políticas do florianismo. Abafada a Revolta, é enviado para a Ilha das Enxadas, com a função de carcereiro, onde presencia um sumário fuzilamento, por ordens expressas de Floriano Peixoto, dos prisioneiros de guerra, ex-membros da Marinha. Quando Quaresma toma consciência da manobra, redige uma carta de censura ao presidente, exigindo dele que se respeitassem os direitos humanos dos rebeldes. Em conseqüência de sua carta, o grande florianista é preso e enviado para a Ilha das Cobras, onde teria o mesmo fim dos prisioneiros por cujos direitos protestara.

Eis, então, o triste fim de Policarpo Quaresma, o major visionário (nas próprias palavras do autoritário Floriano Peixoto), morto efetivamente por subversão ao governo, mas que, de fato, morrera bem antes disso ao ver cada um dos seus projetos de construção do futuro para o país sucumbir diante das dificuldades do Real. Por conseguinte, o discurso expresso dá indícios de um pessimismo, com a morte da própria idealização de um país progressista, pautado no nacionalismo e no respeito ao seu povo humilde; o que vence, enfim, é o autoritarismo de uma sociedade que, em geral, não tem consciência de si mesma, delegando aos dirigentes do país as rédeas dos destinos nacionais.

Conforme Bosi (1992), o desfecho de Quaresma é marcado por um anticlímax devastador em termos psicológicos e de funeral de uma ideologia que foi desmoronada pelo contato com o Real.

Apesar de pessimista, o final de Policarpo Quaresma talvez não signifique o final absoluto de um sonho de modernização para o país: a obra termina com um tom de uma frágil esperança que brota no meio das reflexões de Olga - a afilhada de Quaresma - em relação à sociedade brasileira e às suas transformações ao longo do tempo. É preciso então, nas suas concepções, que o espaço, a mentalidade e os valores mudem para que os esforços de Quaresma sejam enfim reconhecidos. Assim, a última frase inicia-se com um "Esperemos mais...", denotando não a morte, mas o adiamento da constituição de uma pátria verdadeiramente livre, original e mãe do seu povo como queria Policarpo Quaresma e, por que não dizer, o próprio Lima Barreto. 


\section{CONSIDERAÇÕES FINAIS}

Foi inserido na proposta pré-modernista de descoberta do Brasil não-oficial que o escritor carioca Afonso Henriques de Lima Barreto desenvolveu a sua prosa militante, opondo-se à maioria de seus contemporâneos, com uma escrita objetiva e com agudeza crítica quanto à organização socioespacial. Como uma arma, as palavras, na obra de Lima Barreto, serviram para atingir diretamente os valores burgueses e aristocráticos que se destacavam nos anos iniciais da República, no país. Assim, com um caráter de denúncia, as obras barretianas enfocavam, em essência, a opressão social e o autoritarismo da sociedade brasileira.

Simpático aos oprimidos e sentindo na pele a humilhação e a exclusão por sua condição de mulato, Lima Barreto transformou-se em um cético das ideologias 'progressistas' de sua época. Denunciando a decadência moral e intelectual de uma sociedade que, na sua concepção, só buscava "copiar" valores exógenos, ele lançou traços biográficos em todos os seus escritos, reproduzindo críticas e preocupações para com a sociedade fluminense - e por extensão, para com a sociedade brasileira - do final do século XIX e início do século XX. O trabalho aqui em questão apresenta as concepções de Lima Barreto/Policarpo Quaresma acerca dos projetos de modernização do país, considerando com perspicácia a organização social do Rio de Janeiro do início do regime republicano.

Se a análise dos discursos presentes exclusivamente na obra Triste Fim de Policarpo Quaresma não permite entrever um caráter prognóstico sobre o modo pelo qual Lima Barreto acreditava que deveria se operar a formação territorial e a construção da identidade nacional brasileiras, o caráter diagnóstico acerca dos modelos adotados para a nossa formação territorial - ou seja, os modelos de como se dava, à época, a construção do espaço - pautava-se em duras críticas. Assim, se não ficam evidentes os modelos desejados pelo literato, essa obra permite explorar as concepções de mundo do autor no tocante aos modelos refutados, os quais eram exatamente aqueles que conduziam a construção e o dito progresso do país.

Sem poder considerar de modo absoluto se as proposições barretianas, ou, em outras palavras, se os seus discursos de literato, encontraram uma legitimação e materialização no Real, é possível intuir que, dado a perpetuidade dos traços repudiados pelo autor - como a segregação socioespacial nas cidades; a pobreza e a falta de incentivo nos campos; e o caráter autoritário mascarado da sociedade brasileira - Lima Barreto foi um intelectual "vencido"; nessa condição, ele teve que se submeter aos desejos e desígnios, às concepções de mundo de um grupo que, social, política, cultural e economicamente, ditou os rumos e as escolhas assumidas pelo país. Esse é o grande mérito do trabalho ao tentar "equilibrar" a autonomia estética e artística da Literatura com a sua autêntica genética discursiva, socioideológica e historicamente assentada, de modo que a retórica artístico-literária configura-se como um produto mais complexo do que um mero resultado do indivíduo escritor, resultado este que é reverberado proeminentemente na maioria das análises desenvolvidas no âmbito da Geografia e Literatura.

Para uma efetiva aferição da eficácia política dos discursos barretianos, as pesquisas precisam caminhar no sentido de amadurecer uma investigação da recepção dos discursos, e não somente da sua produção, buscando verificar em que medida as retóricas artísticas foram efetivamente usadas para legitimar as propostas e projetos estatais-nacionais e para "preparar" a população para que as políticas e ações do Estado e dos agentes sociais fossem corroboradas e validadas. Estes são caminhos futuros a serem percorridos.

Em Triste Fim de Policarpo Quaresma se expressa com profundidade a dinâmica da sociedade brasileira em que os preconceitos de cor refletem todos os demais preconceitos de cultura e de condição social, o que permite ao autor contrapor-se às ideologias cientificistas que apresentavam a inferioridade nacional como decorrência da composição racial do país. Ao tratar com o funcionário público Policarpo Quaresma, o autor consegue evidenciar a trama da composição social carioca a partir de uma classe média nascente, perdida entre os interesses aristocráticos ditadores de toda a ordem e a singeleza dos pobres. Estes últimos são apresentados em sua ignorância, em seus recursos 
parcos, no uso do espiritualismo a fim de compensar sua exclusão do mundo dos ricos. A cultura popular tem um destaque especial na obra e é mostrada como a verdadeira essência nacional, mas nem por isso deixa de receber o olhar crítico e ácido do autor.

Triste Fim de Policarpo Quaresma apresenta-se, enfim, como uma literatura de tom irônico aos valores arrivistas, diletantes e mesquinhos da sociedade, à desorganização espacial e à discriminação dos habitantes dos subúrbios, além de expressar uma devastadora ruptura com o quixotesco sonho do protagonista de ver a "ascensão da pátria" por meio da modernização do país. Essa obra, portanto, ao resgatar como Lima Barreto entendia o que era e como deveria ser o Brasil, apresenta-se como um importante recurso para compreender o pensamento naquele momento histórico. $\mathrm{O}$ discurso veiculado pelo autor permite ainda resgatar as transformações sociais que estavam em curso, bem como os pensamentos e projetos de modernização presentes à época, e quais deles encontraram legitimação política e, consequentemente, materialização concreta no Real.

Procuramos aqui apreender o discurso de Lima Barreto no que ele pode contribuir para a compreensão do pensamento geográfico entre o final do século XIX e o início do XX, levando em consideração a máxima consciência possível para o autor, ou seja, quanto ele conseguiu compreender a sociedade de seu tempo, a partir do contexto e da classe social nos quais estava inserido. Os projetos de modernização do Brasil, naquele período, refletem opções que a elite estava fazendo para a sociedade brasileira como um todo e aquelas escolhas determinaram, em grande parte, o que somos hoje. Nossa espacialidade está impregnada daquelas escolhas e é nesse sentido que cabe procurar resgatar o embate político e ideológico daquele momento.

\section{REFERÊNCIA BILIOGRÁFICA}

BARRETO, Afonso Henriques de Lima. A volta. Correio da Noite, Rio de Janeiro, 26 jan. 1915. In: FOLHA DE S. PAULO. Lima Barreto: Crônicas Escolhidas. São Paulo: Ática, 1995. p.95-7.

BARRETO, Afonso Henriques de Lima. Triste Fim de Policarpo Quaresma. São Paulo: Klick, 1997. 191p. (Coleção Ler É Aprender, n.18, O Estado de S. Paulo).

BOSI, Alfredo. O Pré-Modernismo. 4.ed. São Paulo: Cultrix, 1973. Série: A Literatura brasileira.

BOSI, Alfredo. Sob o signo de Cam. In: Dialética da colonização. 2.ed. São Paulo: Companhia das Letras, 1992. p. 246-272.

CANDIDO, Antônio. Literatura e sociedade. 5.ed. São Paulo: Nacional, 1976.

CANDIDO, Antônio. Literatura de dois gumes. In: A educação pela noite e outros ensaios. São Paulo: Ática, 1987.

DE NICOLA, José. Literatura Brasileira: da origem aos nossos dias. 15.ed. São Paulo: Scipione, 1998. GOLDMANN, Lucien. Ciências humanas e Filosofia. Que é sociologia? Rio de Janeiro: DIFEL, 1993. GOLDMANN, Lucien. Dialética e Cultura. Trad. Luiz Fernando Cardoso, Carlos Nelson Coutinho e Giseh Vianna Konder. 2.ed. Rio de Janeiro: Paz e Terra, 1979.

INFANTE, Ulisses. Curso de Literatura de Língua Portuguesa. São Paulo: Scipione, 2001.

MACHADO, Lia Osório. Origens do pensamento geográfico no Brasil: meio tropical, espaços vazios e a idéia de ordem (1870-1930). In: CASTRO, Iná Elias; GOMES, Paulo César da Costa; CORRÊA, Roberto Lobato (Orgs.). Geografia: Conceitos e Temas. 8.ed. Rio de Janeiro: Bertrand Brasil, 2006. p.309-352.

MELO, Rita. Lima Barreto, a cidade e os "homens do subterrâneo" nos primeiros anos da República. História e Perspectivas, Uberlândia, n.27/28, p.537-556, jul./dez.2002; jan./jun. 2003. ISSN 0103-409X.

MILLIET, Sérgio. Noticiário. O Estado de S. Paulo, São Paulo, 11 nov. 1948.

PENTEADO MARTHA, Alice Áurea. Lima Barreto e a crítica (1900-1922): a conspiração de silêncio. Acta Scientiarum, Maringá, v.22, 2000. ISSN 1415-6814. Disponível em: http://periodicos.uem.br/ojs/index.php/ ActaSciHumanSocSci/issue/view/236. Acesso em: jan. 2009. 
ROSSO, Mauro. O conto em Lima Barreto. Junho/2006. Disponível em: http://www.germinaliteratura. com.br/literaturamr_mai2006.htm. Acesso em: jan. 2009.

SEVCENKO, Nicolau. Literatura como Missão: Tensões Sociais e Criação Cultural na Primeira República. 2.ed. rev. e ampl. São Paulo: Companhia das Letras, 2003.

Trabalho enviado em janeiro de 2012

Trabalho aceito em fevereiro de 2012 